\title{
MEMPREDIKSI PENYIMPANGAN INTERPERSONAL DARI KEADILAN PROSEDURAL DAN KEADILAN INFORMASIONAL
}

\author{
Ema Nurmaya \\ Universitas Ahmad Dahlan \\ ema.nuryama@mgm.uad.ac.id
}

\begin{abstract}
The objective of this study is to investigate the effect of procedural and informational justice on interpersonal deviance. Specifically, this study hypothesizes that: (a) There is a negative effect of procedural justice on interpersonal deviance behavior, (b) There is a negative effect of informational justice on interpersonal deviance behavior. To test the hypothesis, SPSS was employed to analyze survey data from 124 nurses at general private hospitals in Yogyakarta. The results show that all hypotheses are supported. And furthermore, this study produces suggestions both theoretically and practically.
\end{abstract}

Keywords: Procedural Justice; Informational Justice; Interpersonal Deviance

\section{PENDAHULUAN}

Persaingan yang meningkat di antara organisasi saat ini telah mendorong manajer untuk meningkatkan efektivitas organisasi. Pencapaian efektivitas organisasi dapat dicapai melalui penanaman perilaku positif pada karyawan serta memastikan mereka tidak terlibat dalam perilaku negatif. Oleh karena itu, manajer harus memastikan karyawannya tidak berperilaku negatif. Ada banyak bentuk perilaku negatif, dan salah satu yang paling sering diteliti adalah penyimpangan di tempat kerja yang menjadi salah satu bentuk perilaku melanggar norma organisasi (Griffin, 2005). Agervold (2009) mengatakan bahwa ketidaksopanan di tempat kerja dijelaskan sebagai jenis interaksi sosial dimana pelaku menggunakan komunikasi verbal atau non verbal yang disertai unsur negatif dan agresif yang berfokus pada kepribadian dan harga diri dari penerima yang dituju.

Ada dua tipe perilaku menyimpang di tempat kerja, yaitu penyimpangan organisasional (organizational deviance) dan penyimpangan interpersonal (interpersonal deviance) (Bennett, 2000). Walaupun kedua macam penyimpangan ini membawa implikasi yang buruk terhadap perusahaan, namun studi terkait dengan penyimpangan interpersonal masih relatif sedikit dibanding dengan studi penyimpangan organisasional. Maka dari itu, penelitian ini akan berfokus pada studi penyimpangan interpersonal di tempat kerja.

Seperti halnya penyimpangan organisasional, kejadian penyimpangan interpersonal akan membawa implikasi negatif bagi perusahaan, misalnya perusahaan harus menanggung biaya-biaya sebagai akibat perilaku menyimpang tersebut, moral kerja karyawan yang menurun, ketakutan yang meningkat, ketidakamanan kerja, dan sebagainya. Terlebih lagi untuk penyimpangan interpersonal akan ada akibat tambahan lainnya, yaitu berakibat buruk baik secara psikologis maupun fisik yang dialami langsung oleh karyawan yang menjadi sasaran perilaku menyimpang tersebut (Griffin, 1998). 
Mempertimbangkan dampak yang negatif dari perilaku penyimpangan interpersonal, beberapastuditelahdilakukanuntukmengetahui faktor-faktor yang mempengaruhi perilaku menyimpang tersebut. Salah satu faktor yang cukup mendapatkan perhatian adalah faktor situasional, yaitu keadilan organisasi. Keadilan organisasi adalah persepsi karyawan tentang sejauh mana mereka merasa diperlakukan adil oleh organisasi. Keadilan organisasi dapat dibedakan menjadi empat, yaitu keadilan distributif, keadilan prosedural, keadilan interpersonal, dan keadilan informasional (Colquitt, 2001; Cropanzano et al., 2007; Amiri et al., 2013). Keadilan prosedural dan informasional adalah dua tipe keadilan yang masih sedikit mendapat perhatian terkait dengan hubungannya terhadap penyimpangan interpersonal. Maka dari itu, penelitian ini berfokus untuk menelaah pengaruh keadilan prosedural dan informasional terhadap kejadian dari penyimpangan interpersonal.

\section{REVIEW LITERATUR DAN HIPOTESIS}

\section{Landasan Teori}

\section{Penyimpangan Interpersonal (Interpersonal Deviance)}

Penyimpangan interpersonal merupakan bagian dari penyimpangan di tempat kerja. Robinson (1995) mengembangkan tipologi penyimpangan berdasarkan dua dimensi dasar yaitu tingkat keparahan dan target. Seperti yang ditunjukkan pada gambar 2.1 penyimpangan tempat kerja akan bervariasi di sepanjang kedua dimensi ini. Berdasarkan kedua dimensi tersebut, Robinson (1995) mengklasifikasikan penyimpangan tempat kerja menjadi empat kategori, yaitu penyimpangan properti, penyimpangan produksi, penyimpangan politik, dan agresi pribadi. Berikut adalah topologi empat kategori penyimpangan di tempat kerja:

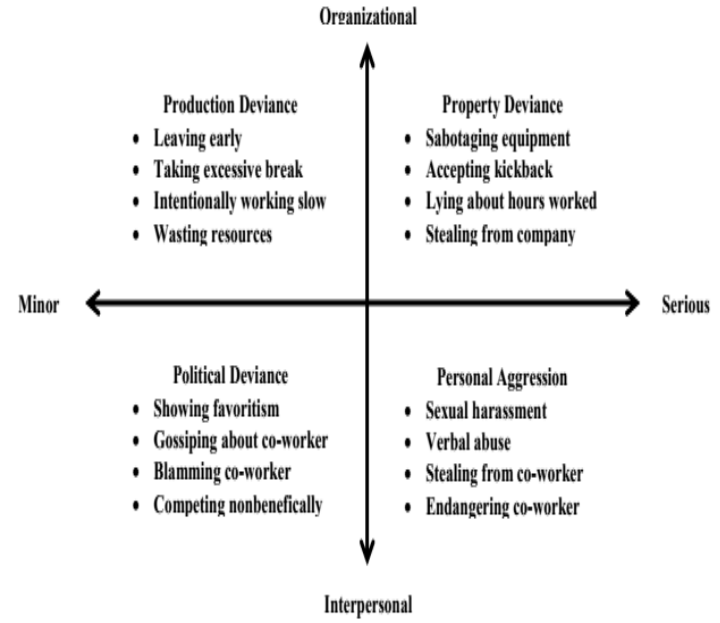

Gambar 2.1

Topologi Penyimpangan Organisasi

\section{Keadilan Organisasi}

Fatimah et al., (2011) mengatakan keadilan organisasional menggambaran persepsi individu dari perlakuan yang diterima dari sebuah organisasi dan reaksi perilaku untuk perseps tersebut, serta keadilan organisasi juga dapat didefinisikan sebagai studi kesetaraan di tempat kerja. Kerangka kerja organisasi mengacu pada keadilan dan perilaku etis dalam sebuah organisasi. Keadilan organisasi didefinisikan sebagai perasaan pribadi atas upah dan tunjangan yang adil (Farahbod, 2013).

Menurut Adam (1965) karyawan akan menilai keadilan distributif berdasarkan teori ekuitas, dimana orang cenderung menjaga keseimbangan antara output dan input. Dengan demikian, dalam hubungan kerja, karyawan mengevaluasi keadilan dalam organisasi berdasarkan rasio hasil yang mereka terima dari organisasi (misalnya, gaji, tunjangan, dan promosi) dengan masukan yang mereka berikan kepada organisasi (misalnya, pendidikan, kecerdasan, pengalaman, usaha dan stres), dan kemudian membandingkan rasio itu dengan rasio yang sama dari pekerja rujukan (Adam, 1965).

Pada pertengahan tahun 1970 an, beberapa peneliti lainnya berpendapat bahwa karyawan tidak hanya mempertimbangkan hasil dalam 
mengevaluasi keadilan dalam organisasi, tetapi juga prosedur distribusi hasil yang diterima (Colquitt, et al., 2005). Jadi, jika keadilan distributif lebih terkait dengan evaluasi hasil yang diterima, keadilan prosedural lebih terkait dengan evaluasi sistem organisasi (Greenberg, 1990). Kemudian di tahun 1980-an, para peneliti berfokus pada keadilan interaksional mengemukakan bahwa seorang karyawan mempertimbangkan hasil, prosedur distribusi hasil, dan perlakuan interpersonal dalam mengevaluasi keadilan dalam organisasi. Oleh karena itu, mereka memperkenalkan konsep keadilan interaksional yang mereka definisikan sebagai sejauhmana seorang karyawan memandang dia diperlakukan dengan sopan, jujur, dan hormat ketika prosedur distribusi hasil diimplementasikan (Bies, 1986; Tyler, 1990).

Dalam perkembangannya para peneliti membagi keadilan interaksional menjadi keadilan interpersonal dan informasional (Colquitt, 2001; Colquitt et al., 2001). Keadilan antarpribadi mengacu pada sejauh mana seorang karyawan memandang dia diperlakukan dengan sopan, bermartabat, dan hormat oleh orang-orang yang memegang otoritas dalam melaksanakan prosedur distribusi hasil. Keadilan informasional di sisi lain mengacu pada sejauhmana penjelasan diberikan tentang mengapa prosedur digunakan dan bagaimana hasil didistribusikan (Colquitt 2001; Colquitt et al., 2001).

\section{Hipotesis}

1. Pengaruh Negatif Keadilan Prosedural terhadap Penyimpangan Interpersonal

Menurut Kreitner (2014) keadilan prosedural merupakan keadilan yang dirasakan dari proses dan prosedur yang digunakan untuk mengalokasikan keputusan. Greenberg (2010) menambahkan bahwa keadilan prosedural merupakan keadilan yang dirasakan dari proses dimana keputusan organisasi dibuat. Robinson (1997) menjelaskan bahwa perlakuan tidak adil atau persepsi ketidakadilan dapat memicu atau memprovokasi karyawan untuk melakukan perilaku menyimpang melalui perasaan disparitas dan kemarahan sebagai upaya untuk memulihkan atau mengungkapkan ketidakadilan yang mereka alami.

Dengan demikian, ketika karyawan mempersepsikan adanya ketidakadilan prosedural, dimana mereka merasa bahwa prosedur atau sistem distribusi hasil yang diterima atau balas jasa (gaji, tunjangan-tunjangan, promosi, fasilitas, dan lain-lain) yang dia terima tidak sesuai dengan harapan mereka. Hal ini akan menimbulkan perasaan disparitas dari apa yang mereka harapkan dengan apa yang mereka dapatkan, dan juga kondisi ini akan membuat mereka marah dan kecewa. Hal ini selanjutnya akan mendorong mereka terlibat dengan perilaku penyimpangan interpersonal misalnya, mengatakan sesuatu yang menyakitkan, bertindak kasar, membahayakan orang lain, bergosip dan atau mencuri dari mereka (bisa rekan kerja, atasan atau bawahan) yang mereka persepsikan sebagai orang yang bertanggung jawab pada implementasi dari keadilan prosedur tersebut.

Penelitaian terdahulu juga memberikan bukti bahwa keadilan prosedural berpengaruh secara negatif terhadap perilaku penyimpangan interpersonal (Berry et al., 2007; Kusumawati, 2015). Artinya ketika karyawan mempersepsikan adanya keadilan prosedural yang tinggi maka perilaku penyimpangan interpersonal mereka akan rendah, mereka akan sedikit terlibat dengan perilaku penyimpangan secara interpersonal. sebaliknya bila mereka mempersepsikan adanya keadilan prosedural rendah maka perilaku penyimpangan interpersonal mereka akan tinggi. Berdasarkan uraian ini maka diduga ada hubungan atau pengaruh negatif dari keadilan prosedural terhadap perilaku penyimpangan interpesonal, 
seperti hipotesis pertama berikut:

\section{H1 :Terdapat Pengaruh Negatif Keadilan Prosedural terhadap Penyimpangan Interpersonal}

\section{Pengaruh Negatif Keadilan Informasional terhadap Penyimpangan Interpersonal}

Cruceru (2009) menjelaskan keadilan interaksional merupakan keadilan yang berkaitan dengan perilaku para pemimpin perusahaan dalam melaksanakan keputusan mereka. Herman (2013) menambahkan bahwa keadilan interaksional merupakan perlakuan interaksional yang diambil oleh pembuat keputusan (decision maker) antar personal dalam organisasi.

Demikian halnya dengan kondisi dimana karyawan mempersepsikan bahwa terdapat ketidakadilan informasional. Karyawan mengharapkan organisasi memberikan atau menyediakan penjelasan-penjelasan ataupun berbagai macam informasi terkait dengan prosedur yang digunakan untuk mendistribusikan balas jasa (gaji, upah, promosi, tunjangantunjangan, fasilitas-fasilitas) yang mereka terima. Dan apabila ternyata informasiinformasi tersebut tidak tersedia maka mereka akan mempersepsikan bahwa perusaahan tidak adil terhadap mereka. Hal ini akan menimbulkan rasa disparitas dan perasaan marah, yang pada akhirnya mendorong mereka berperilaku menyimpang terhadap orang-orang yang mereka anggap bertanggung jawab terhadap ketidaktersediaan informasi yang mereka harapkan.

Studi terdahulu memberikan bukti bahwa keadilan informasional berpengaruh secara negatif terhadap perilaku reaksi negatif (negative reaction) (Colquitt et al., 2001). Jadi ketika persepsi keadilan informasional tinggi atau dengan kata lain karyawan merasa diperlakukan adil secara informasional maka perilaku penyimpangan interpersonal mereka akan rendah dan sebaliknya. Dari uraian ini, maka diduga ada pengaruh negatif dari keadilan organisasi terhadap perilaku penyimpangan interpersonal, seperti tertuang dalam hipotesis kedua berikut:

H2 :Terdapat Pengaruh Negatif Keadilan Informasional terhadap Penyimpangan Interpersonal

\section{Model Penelitian}

Gambar 2.2

Model Penelitian

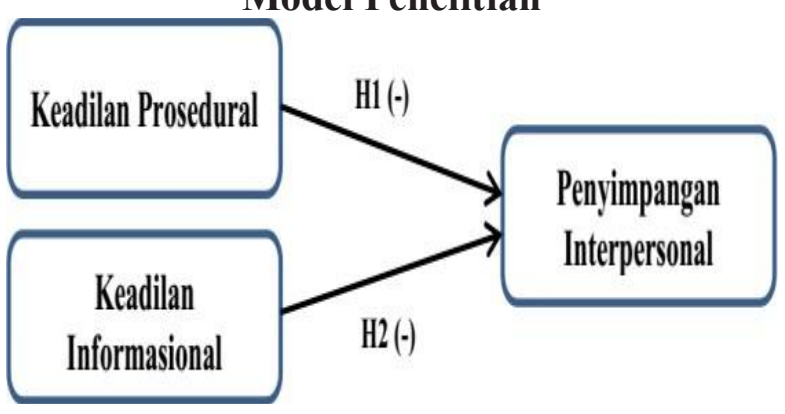

\section{METODE PENELITIAN}

\section{Populasi dan Sampel}

Survei kuesioner yang memuat pengantar yang menjelaskan tujuan penelitian, yang menyatakan bahwa penelitian dilakukan semata-mata untuk tujuan akademis, menjamin anonimitas dan kerahasiaan, serta meminta kejujuran dalam mengisi kuesioner, 7 item untuk menilai penyimpangan interpersonal, 5 item untuk mengukur keadilan informasional, 7 item untuk menilai keadilan prosedural dan informasi demografis seperti jenis kelamin, usia, masa kerja dan pendidikan responden dibagikan kepada responden. Sebelum menyebarkan survei kuesioner, peneliti secara pribadi menghubungi bagian sumber daya manusia rumah sakit swasta umum di Yogyakarta untuk mendapatkan persetujuan guna menyebarkan kuesioner.

Setelah mendapat persetujuan, satu asisten diminta untuk membantu di lapangan guna mendistribusikan dan mengumpulkan kuesioner. Responden penelitian ini adalah pegawai rumah sakit. Secara spesifik, sampel penelitian adalah perawat dari rumah sakit swasta umum di Yogyakarta Indonesia. 
Pesertanya adalah perawat operasional. Dari 140 kuesioner yang dibagikan, 126 kuesioner dikembalikan. Jadi tingkat tanggapannya adalah 90\%. Dua dari 126 kuesioner yang dikembalikan tidak dapat digunakan karena tidak lengkap, sehingga hanya 124 kuesioner yang dapat digunakan. Dari 124 responden, 86 persen berjenis kelamin perempuan $(69,4 \%)$, 100 responden berstatus menikah $(80,6 \%)$, dan paling sedikit 54 persen memiliki ijazah diploma. Rata-rata umur 35 tahun (s.d. $=8,89$ ), dan rata-rata masa kerja 8,42 tahun (s.d. = $5,45)$.

\section{Variabel Penelitian}

\section{Variabel Dependen}

Variabel dependen atau variabel endogen (endogeneous) adalah variabel yang dianggap dipengaruhi oleh variabel lain dalam model. Dan menjadi fokus dan alasan mengapa variabel ini penting dalam suatu penelitian. Dalam penelitian ini variabel dependennya adalah perilaku penyimpangan interpersonal. Perilaku penyimpangan interpersonal adalah perilaku negatif yang ditujukan atau dengan target individu lain didalam organisasi atau lingkungan kerja.

\section{Variabel Independen}

Variabel independen atau variabel eksogen (exogenous) adalah variabel yang dianggap memiliki pengaruh terhadap variabel yang lain, namun tidak dipengaruhi oleh variabel lain dalam model. Dalam studi ini variabel independen atau eksogen ada dua yaitu keadilan prosedural dan keadilan informasional. Keadilan prosedural berterkaitan dengan sejauhmana karyawan mempersepsikan keadilan prosedur atau sistem yang digunakan atas balas jasa yang karyawan terima. Kemudian keadilan informasional berterkaitan dengan sejauhmana karyawan mempersepsikan terhadap ketersediaan informasi dan penjelasan ke atas prosedur terkait dengan balas jasa yang karyawan terima.

\section{HASIL PENELITIAN DAN PEMBAHASAN}

\section{Uji Analisis Data}

\section{Validitas Intrumen}

Dalam penelitian ini, penyimpangan interpersonal (Interpersonal Deviance) akan diukur menggunakan alat ukur yang dikembangkan oleh Robinson (2000). Ini terdiri dari tujuh item. Responden diminta untuk menilai sejauh mana mereka telah terlibat dalam setiap perilaku penyimpangan pada skala tipe Likert lima poin mulai dari 1 (tidak pernah) hingga 5 (selalu). Contoh item pertanyaan misalnya: "Mengolok-olok seseorang di tempat kerja" dan "Mengatakan sesuatu yang menyakitkan kepada seseorang di tempat kerja". Penelitian sebelumnya melaporkan keandalan Cronbach's Alpha untuk rentang skala ini antara 0,81 hingga 0,87 (Bennett, 2000; Diefendorff, 2007).

Keadilan prosedural (procedural justice) akan diukur dengan alat ukur yang dikembangkan oleh Colquitt (2001), terdiri dari tujuh item. Responden diminta untuk menunjukkan sejauhmana mereka setuju atas pernyataan tentang prosedur yang digunakan untuk menentukan hasil atau balas jasa yang mereka terima dari organisasi. Pernyataan tersebut berada pada skala Likert lima poin yang berkisar dari " 1 = sangat tidak setuju" hingga "5 = sangat setuju". Contoh item pertanyaan di antaranya: "Prosedur tersebut telah didasarkan pada informasi yang akurat" dan "Prosedur tersebut telah menjunjung standar etika dan moral".

Keadilan informasional (informational justice) akan diukur dengan menggunakan skala yang dikembangkan oleh Colquitt (2001) yang terdiri dari lima item. Responden diminta untuk menunjukkan sejauhmana mereka setuju atas pernyataan terhadap orang atau figur otoritas yang menjalankan prosedur. Pernyataan tersebut berada 
pada skala Likert lima poin yang berkisar dari " 1 = sangat tidak setuju" hingga " 5 = sangat setuju". Contoh Item pertanyaan di antaranya: "Dia telah menjelaskan prosedur secara", "Penjelasannya mengenai prosedur tersebut masuk akal" dan "Dia telah mengkomunikasikan detail secara tepat waktu".

Untuk memastikan bahwa instrumen betul-betul bisa mengukur konstruk yang akan diukur, maka dilakukan uji validitas (Ghozali dalam Hafisa, 2018). SPSS digunakan untuk menganalisis validitas instrumen, dengan melakukan alisis pearson product moment (Sugiyono, 2005). Hasilnya menunjukkan, beberapa item harus dihapus karena tidak valid. Berikut adalah item akhir untuk setiap instrumen pengukuran: Keadilan prosedural memiliki 6 item, keadilan informasional memiliki 4 item, dan interpersonal deviance 7 item. Tabel 3.1 menyajikan hasil keseluruhan uji validitas.

Tabel 4.1

Hasil Uji Validitas

\begin{tabular}{|c|c|c|c|c|}
\hline Variabel & Item & $\begin{array}{c}\text { Correcte } \\
\text { d item_ } \\
\text { Total } \\
\text { Item } 124\end{array}$ & $\begin{array}{c}\text { R } \\
\text { Table }\end{array}$ & Ket \\
\hline \multirow{7}{*}{$\begin{array}{c}\text { Penyimpangan } \\
\text { Interpersonal }\end{array}$} & 1 & 0,736 & 0,176 & Valid \\
\hline & 2 & 0,666 & 0,176 & Valid \\
\hline & 3 & 0,522 & 0,176 & Valid \\
\hline & 4 & $\overline{\mathbf{0 , 7 2 2}}$ & 0,176 & Valid \\
\hline & 5 & 0,699 & 0,176 & Valid \\
\hline & 6 & $\mathbf{0 , 5 5 1}$ & 0,176 & Valid \\
\hline & 7 & 0,568 & 0,176 & Valid \\
\hline \multirow{7}{*}{$\begin{array}{c}\text { Keadilan } \\
\text { Prosedural }\end{array}$} & 1 & $\mathbf{0 , 5 8 6}$ & 0,176 & Valid \\
\hline & 2 & $\overline{0,600}$ & 0,176 & Valid \\
\hline & 3 & 0,753 & 0,176 & Valid \\
\hline & 4 & 0,153 & 0,176 & Invalid \\
\hline & 5 & 0,569 & 0,176 & Valid \\
\hline & 6 & 0,697 & 0,176 & Valid \\
\hline & 7 & $\overline{\mathbf{0 , 7 0 7}}$ & 0,176 & Valid \\
\hline \multirow{5}{*}{$\begin{array}{c}\text { Keadilan } \\
\text { Informasional }\end{array}$} & 1 & $\overline{\mathbf{0 , 8 0 0}}$ & 0,176 & Valid \\
\hline & 2 & $\mathbf{0 , 8 7 1}$ & 0,176 & Valid \\
\hline & 3 & $\mathbf{0 , 8 8 7}$ & 0,176 & Valid \\
\hline & 4 & $\mathbf{0 , 8 0 8}$ & 0,176 & Valid \\
\hline & 5 & 0,161 & $\mathbf{0 , 1 7 6}$ & Invalid \\
\hline
\end{tabular}

\section{Reliabilitas Instrumen}

Analisis selanjutnya adalah analisis reliabilitas untuk memastikan bahwa jawaban seseorang terhadap pertanyaan adalah konsisten atau stabil dari waktu ke waktu (Ghozali dalam Hafisa, 2018). Analisis ini dilakukan dengan menggunakan SPSS yang hasilnya adalah seperti disajikan dalam tabel 3.2 dimana keadilan prosedural memiliki Cronbach's Alpha 0,712; keadilan informasional memiliki Cronbach's Alpha 0,862; dan penyimpangan antarpribadi memiliki Cronbach's Alpha 0,731.

Tabel 4.2

Hasil Uji Reliabilitas

\begin{tabular}{|c|c|c|c|}
\hline Variabel & $\begin{array}{c}\text { Crombach's } \\
\text { Alpha N 124 }\end{array}$ & $\begin{array}{c}\text { Batas } \\
\text { Kritis }\end{array}$ & Keterangan \\
\hline $\begin{array}{c}\text { Penyimpangan } \\
\text { Interpersonal }\end{array}$ & $\mathbf{0 , 7 3 1}$ & $\mathbf{0 , 7}$ & Reliabel \\
\hline $\begin{array}{c}\text { Keadilan } \\
\text { Prosedural }\end{array}$ & $\mathbf{0 , 7 1 2}$ & $\mathbf{0 , 7}$ & Reliabel \\
\hline $\begin{array}{c}\text { Keadilan } \\
\text { Informasional }\end{array}$ & $\mathbf{0 , 8 6 2}$ & $\mathbf{0 , 7}$ & Reliabel \\
\hline
\end{tabular}

Uji Statistik Deskriptif, Reliabilitas Alpha, dan Korelasi Antar Variabel

Tabel 4.3 menunjukkan hasil statistik deskriptif, dan reliabilitas alpha untuk penelitian ini:

Tabel 4.3

Hasil Uji Statistik Deskriptif, Reliabilitas Alpha, dan Korelasi Antar Variabel

\begin{tabular}{|c|c|c|c|c|c|c|c|}
\hline $\begin{array}{l}\text { Variabel } \\
\text { Unur }\end{array}$ & $\begin{array}{l}\text { Rata2 } \\
355.06\end{array}$ & $\begin{array}{r}50 \\
8.89\end{array}$ & Umur & Kelamin & M. Kerja & Status KP & XF \\
\hline J. Kelamin & 131 & .46 & .08 & & & & \\
\hline M. Kerja & 8.42 & 5.45 & $.74^{* *}$ & .17 & & & \\
\hline Status & 1.17 & .380 & $.555^{* *}$ & .02 & $.44^{* *}$ & & \\
\hline KP & 3.35 & .64 & .04 & .02 & .01 & $\begin{array}{cc}.06 & (, 72)\end{array}$ & \\
\hline $\mathrm{KF}$ & 3.47 & .75 & .00 & .15 & .05 & $=.06 \quad .48^{* *}$ & $(1.86)$ \\
\hline Pl & 1.19 & .28 & .02 & .12 & .01 & $.04 \cdot 24^{* *}$ & $.32^{* *}(7)$ \\
\hline
\end{tabular}




\section{Uji Analisis Regresi}

Tabel 4.4

Hasil Uji Analisis Regresi

\begin{tabular}{|c|c|c|c|}
\hline Hypothesis & B & $t$ & Sig R2 Anova \\
\hline $\begin{array}{l}\text { Procedural justice and Interpersonal } \\
\text { Deviance }\end{array}$ & 0.066 & .1 .98 & $\mu$ \\
\hline $\begin{array}{l}\text { Informational justice and } \\
\text { Interpersoal deviance }\end{array}$ & 104 & .283 & $m$ \\
\hline $\begin{array}{l}\text { Procedural and Informational justice } \\
\text { and organizational Deviance }\end{array}$ & & & "un $\quad .68 \quad F(2,121)=12.179, P<.000)$ \\
\hline
\end{tabular}

Analisis keempat adalah analisis regresi. Regresi berganda dilakukan untuk memprediksi penyimpangan interpersonal berdasarkan keadilan organisasi (keadilan prosedural dan informasional). Tabel 4.4 menunjukkan hasil analisis regresi berganda mengenai prediksi penyimpangan interpersonal berdasarkan keadilan prosedural dan informasional. Ditemukan persamaan regresi yang signifikan $(\mathrm{F}(2,122)=12,179, \mathrm{P}<0,000)$, dengan $\mathrm{R} 2$ sebesar 0,17. Hal ini menunjukkan bahwa keadilan prosedural dan keadilan informasional secara simultan berpengaruh signifikan terhadap penyimpangan interpersonal. Variabel penyimpangan interpersonal mampu dijelaskan oleh variabel keadilan prosedural dan keadilan informasional sebesar $17 \%$, sementara sisanya $83 \%$ dijelaskan oleh variabel lain yang tidak ada dalam penelitian ini.

Hasil analisis regresi berganda pada variabel keadilan prosedural menunjukkan bahwa terdapat pengaruh negatif terhadap penyimpangan interpersonal yang dibuktikan dengan nilai koefisien sebesar -0,086 dan nilai P sebesar 0,005. Hal ini menunjukkan bahwa hipotesis pertama yang mengatakan terdapat pengaruh negatif keadilan prosedural terhadap penyimpangan interpersonal diterima. Kemudian hasil analisis regresi berganda pada variabel keadilan informasional menunjukkan bahwa terdapat pengaruh negatif terhadap penyimpangan interpersonal yang dibuktikan dengan nilai koefisien sebesar -0,104 dan nilai $\mathrm{P}$ sebesar 0,001. Hal ini menunjukkan bahwa hipotesis pertama yang mengatakan terdapat pengaruh negatif keadilan informasional terhadap penyimpangan interpersonal diterima.

\section{Pembahasan}

\section{Pengaruh Negatif Keadilan Prosedural terhadap Penyimpangan Interpersonal}

Hasil analisis regresi berganda pada variabel keadilan prosedural menunjukkan bahwa terdapat pengaruh negatif terhadap penyimpangan interpersonal yang dibuktikan dengan nilai koefisien sebesar $-0,086$ dan nilai P sebesar 0,005 . Hipotesis pertama yang mengatakan terdapat pengaruh negatif keadilan prosedural terhadap penyimpangan interpersonal diterima.

Menurut Kreitner (2014) keadilan prosedural merupakan keadilan yang dirasakan dari proses dan prosedur yang digunakan untuk mengalokasikan keputusan. Greenberg (2010) menambahkan bahwa keadilan prosedural merupakan keadilan yang dirasakan dari proses dimana keputusan organisasi dibuat. Robinson (1997) menjelaskan bahwa perlakuan tidak adil atau persepsi ketidakadilan dapat memicu atau memprovokasi karyawan untuk melakukan perilaku menyimpang melalui perasaan disparitas dan kemarahan sebagai upaya untuk memulihkan atau mengungkapkan ketidakadilan yang mereka alami.

Dengan demikian, ketika karyawan mempersepsikan adanya ketidakadilan prosedural, dimana mereka merasa bahwa prosedur atau sistem distribusi hasil yang diterima atau balas jasa (gaji, tunjangan-tunjangan, promosi, fasilitas, dan lain-lain) yang dia terima tidak sesuai dengan harapan mereka. Hal ini akan menimbulkan perasaan disparitas dari apa yang mereka harapkan dengan apa yang mereka dapatkan, dan juga kondisi ini akan membuat mereka marah dan kecewa. Hal ini selanjutnya akan mendorong mereka terlibat dengan perilaku penyimpangan interpersonal misalnya, mengatakan sesuatu yang menyakitkan, bertindak 
kasar, membahayakan orang lain, bergosip dan atau mencuri dari mereka (bisa rekan kerja, atasan atau bawahan) yang mereka persepsikan sebagai orang yang bertanggung jawab pada implementasi dari keadilan prosedur tersebut.

Penelitaian terdahulu juga memberikan bukti bahwa keadilan prosedural berpengaruh secara negatif terhadap perilaku penyimpangan interpersonal (Berry et al., 2007; Kusumawati, 2015). Artinya ketika karyawan mempersepsikan adanya keadilan prosedural yang tinggi maka perilaku penyimpangan interpersonal mereka akan rendah, mereka akan sedikit terlibat dengan perilaku penyimpangan secara interpersonal. sebaliknya bila mereka mempersepsikan adanya keadilan prosedural rendah maka perilaku penyimpangan interpersonal mereka akan tinggi Berkaitan dengan usaha untuk meningkatkan keadilan prosedural para praktisi bisa melakukan misalnya dengan memperbaiki sistem pemberian balas jasa, sistem penggajian, sistem promosi, sistem pemberian fasilitas dan tunjangantunjangan lain.

\section{Pengaruh Negatif Keadilan Informasional terhadap Penyimpangan Interpersonal}

Hasil analisis regresi berganda pada variabel keadilan informasional menunjukkan bahwa terdapat pengaruh negatif terhadap penyimpangan interpersonal yang dibuktikan dengan nilai koefisien sebesar -0,104 dan nilai $\mathrm{P}$ sebesar 0,001 . Hal ini menunjukkan bahwa hipotesis pertama yang mengatakan terdapat pengaruh negatif keadilan informasional terhadap penyimpangan interpersonal diterima.

Cruceru (2009) menjelaskan keadilan interaksional merupakan keadilan yang berkaitan dengan perilaku para pemimpin perusahaan dalam melaksanakan keputusan mereka. Herman (2013) menambahkan bahwa keadilan interaksional merupakan perlakuan interaksional yang diambil oleh pembuat keputusan (decision maker) antar personal dalam organisasi.

Demikian halnya dengan kondisi dimana karyawan mempersepsikan bahwa terdapat ketidakadilan informasional. Karyawan mengharapkan organisasi memberikan atau menyediakan penjelasan-penjelasan ataupun berbagai macam informasi terkait dengan prosedur yang digunakan untuk mendistribusikan balas jasa (gaji, upah, promosi, tunjangantunjangan, fasilitas-fasilitas) yang mereka terima. Dan apabila ternyata informasiinformasi tersebut tidak tersedia maka mereka akan mempersepsikan bahwa perusaahan tidak adil terhadap mereka. Hal ini akan menimbulkan rasa disparitas dan perasaan marah, yang pada akhirnya mendorong mereka berperilaku menyimpang terhadap orang-orang yang mereka anggap bertanggung jawab terhadap ketidaktersediaan informasi yang mereka harapkan.

Studi terdahulu memberikan bukti bahwa keadilan informasional berpengaruh secara negatif terhadap perilaku reaksi negatif (negative reaction) (Colquitt et al., 2001). Jadi ketika persepsi keadilan informasional tinggi atau dengan kata lain karyawan merasa diperlakukan adil secara informasional maka perilaku penyimpangan interpersonal mereka akan rendah dan sebaliknya. Selanjutnya untuk meningkatkan keadilan informasional, perusahaan hendaknya secara aktif dan pasif memberikan informasi kepada karyawan terkait dengan balas jasa dan prosedurnya. Perusahaan juga harus meningkatkan ketrampilan berkomunikasi dari mereka yang bertanggung jawab pada implementasi prosedur dan penyediaan informasi. 


\section{KESIMPULAN DAN SARAN}

\section{Kesimpulan}

Berdasarkan hasil penelitian di atas, maka dapat disimpulkan bahwa:

1. Hipotesis pertama yang mengatakan terdapat pengaruh negatif keadilan prosedural terhadap penyimpangan interpersonal diterima. Hal ini dibuktikan dengan nilai $\mathrm{P}$ sebesar 0,005 yang mana lebih kecil dari $0,05(0,005<0,05)$.

2. Hipotesis kedua yang mengatakan terdapat pengaruh negatif keadilan informasional terhadap penyimpangan interpersonal diterima. Hal ini dibuktikan dengan nilai $\mathrm{P}$ sebesar 0,001 yang mana lebih kecil dari $0,05(0,001<0,05)$.

\section{Saran}

Saran yang dapat diberikan dalam penelitian ini di antaranya:

1. Penelitian ini menyarankan kepada para manajer untuk meningkatkan keadilan prosedural dan informasional untuk mengurangi kejadian perilaku penyimpangan interpersonal.

2. Untuk pemahaman yang lebih baik terhadap perilaku penyimpangan interpersonal, penelitian selanjutnya disarankan memasukkan variabel lain seperti kepribadian, kepuasan kerja dan pelanggaran kontrak psikologis adalah akan sangat berharga.

\section{DAFTAR PUSTAKA}

Adam, J. (1965). Inequity in Social Exchange. In L. Berkowitz (Eds.), Advances in Experimental Psychology (pp. 267299). New York: Academic Press.

Agervold, M. (2009). Personality and Social Sciences the Significance of Organizational Factors for the Incidence of Bullying. Scandinavian Journal of Psychology, (4), 267-276.
Alias, M. \& Rasdi, R. M. (2014). Organizational Predictors of Workplace Deviance among Support Staff. Procedia-Social and Behavioral Sciences, 172: 126 133.

Amiri, et al., (2012). Evaluation of Effective Fashionism Involvement Factors on Impulse Buying of Costumers and Condition of Interrelation between These Factor. Journal of Basic and Applied Scientific Research, Vol. 2, No. 9, 9413-9419.

Aquino, K., Galperin, B. L. \& Bennett, R. J. (2004). Social Status and Aggressiveness as Moderators of The Relationships Between Interactional Justice and Workplace Deviance. Journal of Applied Social Psychology, 34: 1001-1029.

Aquino, K., Lewis, M. U. \& Bradfield, M. (1999). Justice Construct, Negative Affectivity, and Employee Deviance: A Proposed Model and Empirical Test. Journal of Organizational Behavior, 20: 1073-1092.

Bennett, R. J. \& Robinson, S. L. (2000). Development of A Measure of Workplace Deviance. Journal of Applied Psychology, 85: 349-360.

Berry, C. M., Ones, D. S. \& Sackett, P. R. (2007). Interpersonal Deviance, Organizational Deviance, and Their Common Correlates: A Review and Meta Analysis. Journal of Applied Psychology, 92: 410-424.

Bies, R. J. \& Moag, J. F. (1986). Interactional Justice: Communication Criteria of Fairness. In R. J. Lewicki, B. H. Sheppard, \& M. H. Bazerman (Eds.), Research on Negotiations in Organizations (pp. 43-55). Greenwich, CT: JAI Press. 
Colbert, A. E., Mount, M. K., Harter, J. K., Witt, L. A. \& Barrick, M. R. (2004). Interactive Effect of Personality and Perceptions of The Work Situation on Workplace Deviance. Journal of Applied Psychology, 89: 599-609.

Colquitt, J. A. (2001). On Dimensionality of Organizational Justice: A Construct Validation of A Measure. Journal of Applied Psychology, 86: 386-400.

Colquitt, J. A., Greenberg, J. \& Zapata- Phelan, C. P. (2005). What Is Organizational Justice? A History Overview. In J. Greenberg, J. Colquitt (Eds.), Handbook of Organizational Justice (pp. 3-56). Mahwah, New Jersey: Lawrence Erlbaum Associates.

Colquitt, J. A., Conlon, D. E., Wesson, M. J., Porter, C. L. H. \& Ng, K. Y. (2001). Justice At The Millennium: A MetaAnalytic Review of 25 Years of Organizational Justice Research. Journal of Applied Psychology, 86: 425-445.

Colquitt, J. A., Greenberg, J. \& Zapata- Phelan, C. P. (2005). What Is Organizational Justice? A History Overview. In J. Greenberg, J. Colquitt (Eds.), Handbook of Organizational Justice (pp. 3-56). Mahwah, New Jersey: Lawrence Erlbaum Associates.

Cropanzano R, et al. (2007). The Management of Organizational Justice. Academy of Management Perspectives. Pg 34-38

Cruceru, Raluca and Cristina Macarescu. (2009). Interactional Justice: The Link Between Employee Retention and Employment Lawsuits. Romanian Economic and Business Review, Vol 4 (4): pp. 95-102

Diefendorff, J. M. \& Mehta, K. (2007). The Relations of Motivational Traits with
Workplace Deviance. Journal of Applied Psychology, 92: 967-977.

Dora, M. T. H. and Azim, A. M. M. (2019). Organizational Justice and Workplace Deviance Behavior: Psychological Capital as Mediator. American International Journal of Humanities and Social Science, Vol. 5:2.

Faheem, A. M. \& Mahmud, N. (2015). The Effects of Organizational Justice on Workplace Deviance and Job Satisfaction of Employees: Evidence from a Public Sector Hospital of Pakistan. Mediterranean Journal of Social Sciences, 6:5.

Farahbod, Farzin dkk. (2013). Impact of Organizational Communication in Job Satisfaction and Organizational Commitment (Case Study Maskan Bank Guilan). Interdispinary Journal OfContemporary Research In Business, Vol.5, No.4.

Fatimah, O., Amiraa, A M, and Halim F W. (2011). The Relantionship between Organizational Justice, Organizational Citizenship Behavior and Job Satisfaction. Pertanika Journal Soc, Sci \& Hum, 9, pp: 115-121

Greenberg, J. (1990). Organizational Justice: Yesterday, Today, and Tomorrow. Journal of Management 16: 399-432.

Greenberg, J. (2010). Customer Relationship Management as the Speed of Light: Fourth Edition. New York: McGrawHill.

Griffin, R. W., O’Leary-Kelly, A. \& Collin, J. M. (1998). Dysfunctional Work Behaviors in Organizations, in D.M. Rousseau and C. Cooper, (Eds.), Trends in Organizational Behavior (pp. 65-82). London: John Wiley \& Sons. 
Griffin, R. W. \& Lopez, Y. P. (2005). Bad Behavior in Organizations: A Review and Typology for Future Research. Journal of Management 31: 988-1005.

Hafisa, Dinda Yulia. (2018). Pengaruh Celebrity Endorse terhadap Minat Beli Produk Kosmetik Halal Wardah. Skripsi. Fakultas Ekonomi Universitas Islam Indonesia Yogyakarta.

Herman, Lisa Amelia. (2013). Pengaruh Keadilan Organisasi dan Sistem Pengendalian Intern terhadap Kecurangan (Studi Empiris pada Kantor Cabang Utama Bank Pemerintah di Kota Padang). Jurnal Akuntansi, Vol 1, No 1, 2013.

Hershcovis, M. S., Turner, N., Barling, J., Arnold, K. A., Dupre, K. E., Innes, M., LeBlanc, M. \& Sivanathan, N. (2007). Predicting Workplace Aggression: A Meta-Analysis. Journal of Applied Psychology, 92: 228-238.

Kreitner, Robert dan Angelo Kinicki. (2014). Perilaku Organisasi. Edisi 9. Jakarta: Salemba Empat.

Kusumawati, Yulia, dan Made Surya Putra. (2015). Pengaruh Keadilan Prosedural dan Keadilan Interaksional terhadap Perilaku Retalisasi Karyawan. Jurnal Ekonomi, Universitas Udayana.

Robinson, S. L. \& Bennett, R. J. (1995). A Typology of Deviance Workplace Behavior: A Multidimensional Scaling Study. Academy of Management Journal 38: 555-572.

Robinson, S. L. \& Bennett, R. J. (1997). Workplace Deviance: Its Definition, its Manifestation, and its Causes. In 
EMA NURMAYA

Memprediksi Penyimpangan Interpersonal dari Keadilan Prosedural dan Keadilan Informasional 